\title{
WORKSHOP ISU-ISU STRATEGIS DALAM ALJABAR UNTUK PEMINAT ALJABAR DI KOTA MATARAM
}

\author{
Irwansyah ${ }^{*}$, Mamika Ujianita Romdhini, I Gede Adhitya Wisnu Wardhana, dan Ni Wayan \\ Switrayni \\ Program Studi Matematika FMIPA Universitas Mataram \\ ${ }^{*}$ Korespondensi: irw@unram.ac.id
}

Diterima 30 September 2018 / Disetujui 28 November 2018

\begin{abstract}
ABSTRAK
Matematika merupakan salah satu ilmu yang sangat penting dalam perkembangan peradaban kehidupan manusia. Khususnya aljabar yang merupakan salah satu bidang dalam matematika merupakan tonggak utama dalam perkembangan bidang-bidang ilmu lainnya. Akan tetapi, jumlah hasil-hasil tulisan ilmiah pada bidang ini sangatlah sedikit jumlahnya, khususnya dari kampus-kampus yang ada di Kota Mataram. Hal ini disebabkan karena kurangnya pengetahuan tentang perkembangan penelitian di bidang aljabar dan aplikasinya. Oleh karena itu, kegiatan ini bertujuan untuk meningkatkan motivasi, minat dan pengetahuan khususnya peminat aljabar di Kota Mataram untuk melakukan penelitian dalam bidang aljabar dan aplikasinya. Metode pendekatan yang akan diterapkan adalah melalui workshop yang berisi isu-isu dalam aljabar yang sedang hangat dibicarakan dan beberapa aplikasinya.
\end{abstract}

Kata kunci: Aljabar, Aplikasi Aljabar.

\section{PENDAHULUAN}

Perubahan peradaban dalam kehidupan manusia sangat ditentukan oleh kemajuan ilmu pengetahuan dan teknologi pada masa itu. Hampir semua permasalahan dan tantangan pada setiap masa dapat terjawab secara sainstifik. Matematika yang merupakan salah satu disiplin ilmu pasti sangat banyak berperan dalam memberikan jawaban dari permasalahan dan tantangan tersebut khususnya aljabar.

Secara sederhana, aljabar merupakan cabang matematika yang membawa masalah nyata yang ada di dalam kehidupan sehari-hari ke dalam bentuk persamaan untuk kemudian dicari solusinya. Aljabar dapat dibagi ke dalam dua bagian, yaitu aljabar elementer dan aljabar abstrak. Aljabar elementer merupakan aljabar yang banyak digunakan di bidang sains, ekonomi, teknik, dan kesehatan. Sedangkan, aljabar abstrak merupakan bagian aljabar yang dipelajari terutama oleh para profesional dan pakar matematika (ThoughtCo, 2018). Aljabar telah banyak berperan dalam memberikan jawaban dari permasalahan dan tantangan tersebut, seperti pada komunikasi satelit, komunikasi seluler, keamanan transaksi perbankan, penentuan lokasi dengan GPS, pengiriman gambar planet Mars dan 
Jupiter ke bumi, memori komputer, compact disk, dan lain sebagainya.

Di Indonesia, penelitian aljabar berkembang hanya di beberapa kampus besar seperti Institut Teknologi Bandung, Universitas Gajah Mada, dan beberapa kampus lain di bagian barat Indonesia. Hal ini dapat dilihat dalam partisipasi dan jumlah makalah yang dipresentasikan di pertemuan tahunan Komunitas Peminat Aljabar(KPA) Indonesia. Mengacu pada data yang sama, jumlah makalah bidang aljabar yang dipresentasikan di Seminar KPA yang berasal dari Kota Mataram sangatlah rendah. Fakta ini menunjukkan bahwa penelitian bidang aljabar dan aplikasinya oleh peminat aljabar di Kota Mataram tidak terlalu berkembang.

Salah satu cara untuk mengatasi masalah di atas adalah dengan memberikan workshop yang berisi materi tentang perkembangan aljabar dan aplikasinya. Oleh karena itu, dalam Kegiatan Pengabdian Kepada Masyarakat untuk anggaran DIPA PNBP Unram Tahun 2018, kelompok riset Aljabar dari Program Studi Matematika FMIPA Universitas Mataram mengadakan suatu kegiatan Workshop Isu-isu Strategis dalam Aljabar untuk Mahasiswa Peminat Aljabar di Universitas Mataram.

\section{METODE KEGIATAN}

Metode pendekatan yang diterapkan adalah dengan pola pembimbingan yaitu melalui pemaparan dan diskusi kepada para peminat aljabar di Kota Mataram terkait isu-isu strategis dalam aljabar dan aplikasinya. Tahap awal adalah dimulai dengan menyiapkan materi workshop yang berisi tentang topik-topik aljabar dan aplikasinya dalam kehidupan nyata. Secara umum, topik-topik yang dimaksud adalah sebagai berikut :

1. Bilangan prima dan aplikasinya

2. Aplikasi Matriks dalam kehidupan nyata

3. Hiperplane arrangement

4. Teori pengkodean, persandian, dan aplikasinya dalam teknologi masa kini

Tahap kedua adalah memberikan sosialisasi kepada para peminat aljabar di Kota Mataram terkait dengan pelaksanaan workshop tersebut.

Tahap ketiga adalah pelaksanaan kegiatan Pengabdian Kepada Masyarakat. Kegiatan Pengabdian Kepada Masyarakat ini dilaksanakan di FMIPA Universitas Mataram pada tanggal 27 Oktober 2018.

\section{HASIL DAN PEMBAHASAN}

Melalui kegiatan workshop isu-isu strategis dalam aljabar ini diperoleh informasi sebagai berikut:

1) Para peminat aljabar termotivasi untuk melakukan riset di isu-isu terbaru dalam aljabar dan aplikasinya. Hal ini terlihat dari proses diskusi pada setiap sesi presentasi, dimana para peserta mengajukan beberapa pertanyaan terkait kemungkinan aplikasi konsep dalam presentasi pada masalah riset yang sedang dikerjakan dan adanya rencana kolaborasi riset.

2) Pengetahuan para peserta terkait isuisu terbaru dalam penelitian bidang aljabar dan aplikasinya meningkat. Hal ini disebabkan karena dalam setiap sesi presentasi, tim pengabdian menyajikan masalah-masalah terbuka yang masih belum terselesaikan sampai saat ini khususnya pada teori kode dan aplikasinya, perumuman konsep bilangan prima, hyperplane 
arrangement, dan aplikasi matriks Leslie.

\section{KESIMPULAN DAN SARAN}

\section{Kesimpulan}

Dari pelaksanaan kegiatan workshop isu-isu strategis dalam aljabar, dapat disimpulkan bahwa kegiatan tersebut sangat bermanfaat bagi para peminat aljabar di Kota Mataram, dengan indikator:

1) Meningkatnya motivasi para peminat aljabar untuk melakukan riset di isu-isu strategis terbaru dalam bidang aljabar.

2) Meningkatnya pengetahuan para peminat aljabar terkait isu-isu terbaru dalam penelitian bidang aljabar dan aplikasinya.

\section{Saran}

Perlu dilakukan kegiatan yang serupa untuk keberlanjutan program.

\section{UCAPAN TERIMA KASIH}

Ucapan terima kasih disampaikan kepada Universitas Mataram yang telah mendanai kegiatan Pengabdian Kepada Masyarakat ini melalui sumber dana DIPA BOPTN dan FMIPA Universitas Mataram yang telah menyediakan fasilitas ruangan demi terlaksananya kegiatan ini.

\section{DAFTAR PUSTAKA}

Thoughtco, 2018. Diakses pada Tanggal 25 Mei 2018 pada https://www. thoughtco.com/what-is-algebrawhy-take-algebra-2311937. 